\title{
Transcultural Adaptation Procedures for the Dutch Eating Behavior Questionnaire (DEBQ) for Brazil
}

\author{
Gabriela Salim Xavier Moreira, Diana Cândida Lacerda Mota, Luciana Lorenzato, \\ Idalina Shiraishi Kakeshita, Telma Maria Braga Costa, Sebastião Sousa Almeida ${ }^{1}$ \\ Universidade de São Paulo, Ribeirão Preto-SP, Brasil
}

\section{ABSTRACT}

The objective of this study was to translate the Dutch Eating Behavior Questionnaire (DEBQ) into Brazilian Portuguese and to evaluate the semantic, conceptual, idiomatic and cultural equivalence, content-related validity and level of verbal comprehension as an initial stage of its cross-cultural adaptation. Six stages were conducted: translation, synthesis of translations, back translation, synthesis of back translations; pilot test to evaluate the instrument and verbal comprehension by the target population; and content validity analysis by judges. The differences between the original and translated versions refer to language and culture, as they are very similar in meaning. The content validity index was excellent, with agreement level of $94.50 \%$ among specialists, for the entire scale. The items were easily understood by the target population. The Brazilian version of the DEBQ was approved by the original author and is ready to be tested for psychometric properties.

Keywords: cross-cultural adaptation; translation; validation studies; food behavior.

\section{RESUMO - Procedimentos de Tradução da Adaptação Transcultural do Dutch Eating Behavior Questionnaire (DEBQ) para o Brasil}

O objetivo deste estudo foi traduzir o Dutch Eating Behaviour Questionnaire (DEBQ) para a língua portuguesa do Brasil e avaliar as equivalências semântica, conceitual, idiomática e cultural, validade relacionada a conteúdo e nível de compreensão verbal, como um estágio inicial da sua adaptação transcultural. Seis etapas foram conduzidas: tradução, síntese das traduções, retrotradução, síntese das retrotraduções; teste da versão piloto para avaliar o instrumento e a compreensão verbal pela população alvo; e análise da validade de conteúdo por juízes. As diferenças entre as versões original e traduzida referem-se à linguagem e cultura, pois são muito similares em sentido. O índice de validade de conteúdo foi ótimo, com nível de concordância de $94,50 \%$ entre os especialistas, para a escala inteira. Os itens foram facilmente compreendidos pela população-alvo. A versão brasileira do DEBQ foi aprovada pelo autor original e está pronta para ser testada em relação às propriedades psicométricas.

Palavras-chave: adaptação transcultural; tradução; estudos de validação; comportamento alimentar.

RESUMEN - Procedimientos de Traducción de la Adaptación Transcultural del Dutch Eating Behavior Questionnaire (DEBQ) en Brasil

El objetivo de este estudio fue traducir el Dutch Eating Behaviour Questionnaire (DEBQ) para el idioma portugés de Brasil, y evaluar equivalencia semántica, conceptual, idiomática y cultural, validez relacionada con el contenido, y nivel de comprensión verbal como una etapa inicial de adaptación transcultural. Se llevaron a cabo seis etapas: traducción; síntesis de las traducciones; traducción inversa; síntesis de las versiones de traducción inversa; test de la versión piloto para evaluar el instrumento y comprensión verbal por parte de la población objetivo; y análisis de validez de contenido por jueces. Las diferencias entre la versión original y traducida se refieren a lenguaje y cultura ya que son muy similares en significado. El índice de validez de contenido fue óptimo, con nivel de concordancia de 94,50\% entre los especialistas, para la totalidad de la escala. Los ítems fueron fácilmente comprendidos por la población objetivo. La versión brasileña del DEBQ fue aprobada por el autor original y está lista para ser testada en relación a las propiedades psicométricas. Palabras clave: Adaptación transcultural; traducción; estudios de validación; comportamiento alimentario.

Nutritional trends that have occurred throughout different regions of the world are changing behaviors and lifestyles and contributing to a diet that is richer in fats and sugars. The adoption of sedentary lifestyles, industrial changes, and easy access to various types of food by the majority of the world's population, even in developing countries like Brazil, directly affect health (Batista Filho \& Rissin, 2003). Eating behavior has been considered an important factor in both the prevention and treatment of obesity and many highly prevalent 
diseases in modern societies (Danielsen, Svendsen, Mrhlum, \& Sundgot-Borgen, 2013).

According to Fisberg, Marchioni, and Colucci (2009), eating behavior is one of the main elements of an individual's lifestyle and includes both the choice of food and everything that is related to the daily diet. Eating behavior results from interactions between the consumption of food and such influences as the nutritional, demographic, economic, social, cultural, environmental, and psychological aspects of an individual or a population (Toral \& Slater, 2007).

Given the increasing prevalence of being overweight and obese in Brazil (Brazilian Institute of Geography and Statistics, 2010), properly assessing eating behavior among the Brazilian population is important. Eating behavior can be assessed using the Three Factor Eating Questionnaire (TFEQ; Stunkard \& Messick, 1985) and Dutch Eating Behavior Questionnaire (DEBQ; Van Strien, Frijters Berger, \& Defares, 1986). These are the most widely used instruments for assessing eating behavior and thus the most widely investigated with regard to psychometric properties.

The Brazilian version of the TFEQ-21 (reduced version) was developed by Natacci and Ferreira Junior (2011), whose psychometric evaluation showed satisfactory internal consistency and adequate levels of construct and concurrent validity. The TFEQ focuses more specifically on assessing cognitive restriction.

The DEBQ was developed to measure three eating styles based on three main psychological theories regarding the etiology of overeating: psychosomatic theory, externality theory, and restraint theory (Van Strien et al., 1986). Each of these theories focuses on a type of eating behavior (i.e., emotional, external, and restrained eating) that is evaluated separately by three scales, thus constituting a three-factor structure (Van Strien, 2010). Although Brazilian studies have used the DEBQ, no studies have described the cross-cultural adaptation of the instrument to the Brazilian context or appropriate translation procedures, and no study has presented data on the psychometric properties of the DEBQ among Brazilian samples.

According to psychosomatic theory, individuals who eat in response to emotions, such as anger, fear, or anxiety, do not adequately recognize the internal signals of hunger and satiety, which leads them to excessive food intake in response to emotional arousal and stress (Kaplan \& Kaplan, 1957). Similarly, externality theory postulates that the external environment is a determinant of eating behavior. Overweight individuals are considered to be hyperresponsive to external food-related cues, such as the sight and smell of food, and hyporesponsive to internal physiological signals (Schachter \& Rodin, 1974).

Restraint theory attributes overeating to dieting. This theory is based on the fact that body weight is homoeostatically preserved by the individual so that attempts to decrease body weight through the conscious restriction of food intake can lead to the activation of physiological defense responses, such as a reduction of metabolic rate and persistent hunger. When self-control is lessened by disinhibitors, such as alcohol or excitatory or negative emotions, cognitive restriction is not maintained, and the opposite eating behavior may occur, resulting in excessive food intake. Additionally, restrained eating may result in a loss of contact with feelings of hunger and satiety, which may result in emotional or external eating (Herman \& Polivy, 1975).

The original Dutch version of the DEBQ was published in 1986. In the same year, the English translation of its items was published in the International Journal of Eating Disorders (Van Strien et al., 1986). Since then, the DEBQ has been used by a growing number of researchers in theoretical and etiology studies and experimental, psychometric, and epidemiological investigations.

The DEBQ has been translated into several languages, including German, Spanish, Italian, French, Swedish, Portuguese, Chinese, Greek, and Korean, and exploratory factor analysis and confirmatory factor analysis have confirmed the three-factor structure of each of these translations (Van Strien, 2010). The translation into Portuguese was performed in a cross-cultural adaptation study that was performed in Portugal by Viana and Sinde (2003), showing satisfactory psychometric properties. Studies of the cross-cultural adaptation of the DEBQ showed that it achieved good psychometric indices, regardless of the samples or culture, and the exclusion of items was necessary in only a few cases.

Most studies have indicated that these three eating behaviors are associated with Body Mass Index (BMI; Baños et al., 2011; Bozan, Bas, \& Asci, 2011; Porter \& Johnson, 2011; Ricca et al., 2009; Van Strien, Herman, \& Verheijden, 2009), food consumption (Baños et al., 2011; Ouwens et al., 2003; Porter \& Johnson, 2011; Snoek et al., 2007), and psychological indicators, such as depression, anxiety, and self-esteem (Flament et al., 2012; Goossens et al., 2009; Porter \& Johnson, 2011).

Scales and questionnaires are widely used for clinical evaluation, diagnosis, and screening in the health field. However, if a tool was created for one population and one culture, then it must undergo translation procedures for cross-cultural adaptation and have its psychometric properties tested among different samples. The verification of its psychometric properties can demonstrate that it is a reliable and accurate measurement of a construct (Beaton, Bombardier, Guillemin, \& Ferraz, 2002).

The aim of the present study was to translate the DEBQ into Brazilian Portuguese and evaluate its equivalence, related-content validity, and level of verbal comprehension by the target population as a first step in its cross-cultural adaptation to Brazil. 


\section{Methods}

\section{Dutch Eating Behavior Questionnaire}

The DEBQ has 33 items that are divided into three subscales: restrained eating (10 items), external eating (10 items), and emotional eating (13 items). The emotional eating subscale is divided into two dimensions: emotional eating in response to diffuse emotions (4 items) and clearly labeled emotions (9 items). The questionnaire is self-administered, and all of the items are evaluated using a 5-point Likert-type scale, ranging from "never" (1 point) to "very often" (5 points; Van Strien, 2010).

All of the DEBQ scales have satisfactory to good reliability in various subsamples (Van Strien, 2010). Various international studies of the DEBQ found excellent factorial validity and internal consistency $(\alpha>0.80)$. The presence of three factors was confirmed for the English (Wardie, 1987), German, French, and Swedish (Van Strien, 2010) versions of the DEBQ.

\section{Procedure}

This study was approved by the Academic and Ethics Committee of the University of Ribeirão Preto/ São Paulo (protocol no. 38989114.9.0000.5498), and informed consent was obtained from all of the participants and judges.

The translation procedures were based on guidelines that were proposed by Beaton et al. (2002), which have been adopted nationally and internationally in cross-cultural adaptation studies in different areas (Ferreira, Neves, Campana, \& Tavares, 2014). The translation procedure consisted of five stages: 1 . translation into Brazilian Portuguese, 2. synthesis of translated version, 3. back-translation, 4. pilot study to evaluate the instrument and verbal comprehension by the target population, and 5 . analysis of content validity by judges.

\section{Translation Procedures}

Translation was performed by two independent translators. The first translation (T1) was produced by a language expert and professional translator who was unfamiliar with the assessed construct. The second translation (T2) was produced by a translator who was fluent in English and familiar with the construct. Afterward, the synthesis of T1 and T2 formed a single version (T12) through discussions among expert researchers in the field. Each item was evaluated individually to guarantee semantic, idiomatic, cultural, and conceptual equivalence between versions.

Two independent back-translations were then performed. Both back-translations were conducted by two independent professional translators who were native English speakers, fluent in Brazilian Portuguese, and unfamiliar with the assessed construct and original instrument. Each translator produced his own version of the questionnaire (BT1 and BT2), which were synthesized into a single version (BT12) after discussions between all of the expert researchers who were involved in the study. This version was sent to the author of the original instrument, who confirmed that all of the items were equivalent to the English language version.

\section{Pilot Study}

To verify whether the instructions, response scale, and each item were comprehensible by the target population, the Brazilian version of the DEBQ was applied in a sample of 30 individuals (15 women and 15 men). This sample size was based on guidelines that were proposed by Beaton et al. (2002). The participants were invited to voluntarily participate in the study and were not given any type of financial compensation. Before beginning data collection, the participants signed an informed consent form and completed a sociodemographic questionnaire. Socioeconomic classification was based on parameters that were established by the Brazilian Institute of Geography and Statistics (2015), which divides the Brazilian population into the following five socioeconomic classes according to monthly family income: A, $\mathrm{B}, \mathrm{C}, \mathrm{D}$, and $\mathrm{E}$, where $\mathrm{A}$ is the highest income bracket. Anthropometric and sociodemographic data are described in Table 1.

Afterward, the participants completed the translated version of the DEBQ and then were instructed to indicate the degree to which they comprehended each of the items using a 5-point Likert-type scale, ranging from 0 (did not understand anything) to 5 (understood perfectly and have no doubt). The verbal comprehension scores (mean and standard deviation) of the participants' responses for each question were analyzed. Responses of 0 , 1,2 , and 3 were indicative of insufficient understanding (Conti et al., 2009). Anthropometric measures for all of the participants were then collected, and their nutritional status was classified based on the parameters that were established by the World Health Organization (1998).

\section{Content Validity}

Content validity was assessed by presenting the Brazilian version of the DEBQ to five judges who were experts in eating behavior (one psychologist and four nutritionists). They were chosen based on their experience and qualifications regarding this construct. The experts were invited to participate. Those who accepted signed an informed consent form and then received a letter that contained a description of the dimensions of the questionnaire and each its three subscales. The judges were instructed to read the instrument and identify to which subscale each item belonged (i.e., restrained eating, external eating, and emotional eating). We considered an accuracy rate of $\geq 80 \%$ for each item as the criterion for adequacy as recommended by Pasquali (2001). 
Table 1

Anthropometric and Sociodemographic Characterization by sex (Men: $n=15$; Women: $n=15$ )

\begin{tabular}{|c|c|c|}
\hline & Men $(n=15)$ & Women $(n=15)$ \\
\hline \multicolumn{3}{|l|}{ Age } \\
\hline Mean & 26.33 & 27.13 \\
\hline Standard deviation & 7.77 & 11.94 \\
\hline Minimum - Maximum & $20-57$ & $20-47$ \\
\hline \multicolumn{3}{|l|}{ Socioeconomic class } \\
\hline Class A & $8(53.33 \%)$ & $11(73.33 \%)$ \\
\hline Class B1 & $4(26.67 \%)$ & $2(13.33 \%)$ \\
\hline Class B2 & $2(13.33 \%)$ & $2(13.33 \%)$ \\
\hline Class C1 & $1(6.67 \%)$ & $0(0.00 \%)$ \\
\hline \multicolumn{3}{|l|}{ Weight (kg) } \\
\hline Mean & 77.99 & 65.05 \\
\hline Standard deviation & 15.35 & 13.65 \\
\hline Minimum - Maximum & $53.40-100.20$ & $42.70-89.00$ \\
\hline \multicolumn{3}{|l|}{ Height (m) } \\
\hline Mean & 1.77 & 1.64 \\
\hline Standard deviation & 0.07 & 0.07 \\
\hline Minimum - Maximum & $1.63-1.87$ & $1.51-1.77$ \\
\hline \multicolumn{3}{|l|}{ Body mass index $\left(\mathrm{kg} / \mathrm{m}^{2}\right)$} \\
\hline Mean & 24.93 & 24.09 \\
\hline Standard deviation & 4.10 & 3.79 \\
\hline Minimum - Maximum & $18.05-29.61$ & $17.77-28.96$ \\
\hline \multicolumn{3}{|l|}{ Nutritional status } \\
\hline Underweight & $1(6.67 \%)$ & $3(13.33 \%)$ \\
\hline Normal weight & $5(33.33 \%)$ & $6(40.00 \%)$ \\
\hline Overweight & $9(60.00 \%)$ & $7(46.67 \%)$ \\
\hline Obesity & $0(0.00 \%)$ & $0(0.00 \%)$ \\
\hline
\end{tabular}

\section{Results}

\section{Translation Procedures and Equivalence Evaluation}

For items 2, 4, 6, 19, and 27, the word "usual" was translated as "de costume" to guarantee semantic/linguistic equivalence to the original version, which was back-translated as "usual," similar to the original version. For items 1, 3, 8, 10, 16, 23, 25, 28, 30, and 32 (emotional eating), the expression "have a desire" was translated as "sente vontade" instead of "tem vontade," emphasizing conceptual over semantic equivalence. It was then back-translated as "feel like." For item 10, the expression "lets you down" was translated as "deixa para baixo" instead of both translations suggested the word "decepcionado" to guarantee conceptual equivalence between versions. It was back-translated as "lets you down." For item 13, the word "cross" caused controversy during the translation process. The first translator (T1) suggested the word "bravo." The second translator (T2) suggested the term "mal-humorado." These suggestions were discussed, and the researchers decided to use "contrariado" for T12. For items 9, 15, 21, and 24 , the word "delicious" was translated as "gostoso(a)" to ensure cultural equivalence. It was back-translated as "tasty" because of the semantic meaning of the word. For items 17 and 21, the word "deliberately" was translated as "intencionalmente" because the semantic meaning of the word "deliberadamente" could be not understood by most of the target population. The researchers discussed the behaviors of people who remain on a diet and concluded that such people mostly emphasize the avoidance of fattening foods rather than eating slimming foods. The researchers also considered that not many foods can actually slim someone, whereas some foods have more fat and calories. Therefore, item 24, the translated words "lanchonete" and "café" were back-translated as "snack bar" and "coffee shop," respectively, to guarantee semantic equivalence by considering that the literal translation did not negatively impact comprehension of the item. 


\section{Verbal Comprehension}

The items were easily understood by the target population. Only four items did not receive the maximum score. Among the total sample $(n=30)$, the overall mean comprehension score was $4.98(S D=0.06)$, ranging from $4.60(S D=0.79)$ to $5.00(S D=0.00)$. The lower mean was given to item 4 , which received a score of 2-3 by $13.33 \%$ of the sample.

\section{Content Validity}

The level of agreement among experts for the scale in its entirety was $94.50 \%$. For the emotional eating subscale, the concordance was $95.40 \%$. For the external eating and restrained eating subscales, the level of concordance was $94.00 \%$ for both. When evaluated separately, 29 items had $100 \%$ concordance among the experts, and only three were below the criterion of $80 \%$ (items 3,14 , and 21 ).

\section{Discussion}

Considering the relevance of adapting instruments to other cultures, the procedures for translating the DEBQ to Brazilian Portuguese were conducted according to international guidelines for the cross-cultural adaptation of psychological tests to guarantee that the translated and original versions measured the same construct, with maximum equivalence between them (Beaton et al., 2002; Hambleton, 2005).

During this process, we evaluated semantic, conceptual, cultural, and idiomatic equivalence between the original and translated items. The synthesis of both the translated and back-translated versions was performed through discussions among expert researchers who had experience in the cross-cultural adaptation process and validation studies. This procedure is equivalent to the Expert Committee Review stage that was proposed by Beaton et al. (2002), which advises that consensus should be reached for discrepancies between all versions.

Most of the changes to the translated version were made by considering the common vocabulary that is used by Brazilians who specifically live in urban areas in São Paulo state. Brazil is composed of different regions with cultural regionalisms. Therefore, it is necessary to further evaluate the translated version in other regions, such as the northeast and north.

The main purpose of the back-translation step is to identify inconsistencies between the translated and original versions (Beaton et al., 2002; Hambleton, 2005). The differences between the original and translated versions were attributable to language and culture, which was evident by evaluating the synthesized back-translation and original version because they were quite similar in meaning. No changes to the response scale or format of the entire questionnaire were necessary. The final Brazilian version of the DEBQ was approved by the original author (T. Van Strien).
The fifth and final step of the translation process was a pilot study that verified understanding by a sample of 30-40 individuals of the target population. After this step, the translated version may be returned to the committee of judges, if necessary, to revise the instrument or tailor specific items. The results showed that the translated version was easily understood by Brazilian adults, in which 29 of the 33 items received a verbal comprehension score of 5 . None of the items received comprehension scores $<3$, and the lowest mean score was given to item 4 , which received a score of $2-3$ by only $13.33 \%$ of the sample. Based on these results, the expert committee considered that the synthesized translation that was applied in the pilot study could be considered the final version of the Brazilian DEBQ.

Importantly, the sample in the pilot study was composed of undergraduate students and workers who were recruited in a private university, thus reflecting a sample with higher education. Verbal comprehension of the items should be further evaluated in individuals who have fewer years of education (e.g., elementary school only) to confirm that they are able to answer the instrument appropriately.

With regard to content validity, five experts were asked to classify each question in its respective subscale. We invited three psychologists and three nutritionists, but only one psychologist agreed to participate. Therefore, we included one additional nutritionist. Content-related validity is based on the representativeness, clarity, and relevance of the items that comprise the instruments by judges or specialists (Cassep-Borges, Balbinotti, \& Teodoro, 2010). The results showed 100\% concordance among the experts for the majority of the items (29 of 33), indicating that the Brazilian version of the DEBQ adequately measures the construct of eating behavior. Nevertheless, content-related validity should not replace other types of validity but instead serve as additional confirmation of the psychometric properties of the instrument (Anastasi \& Urbina, 2000).

The next steps in the cross-cultural adaptation process need to be performed to ensure the quality of the adapted instrument. Further psychometric property assessments need to be performed among larger samples to evaluate validity (e.g., factorial analysis and concurrent and discriminant validity) and reliability (e.g., test-retest reliability and internal consistency; Beaton et al., 2002; Hambleton, 2005).

In summary, the objectives of this study were met. The evaluation of qualitative data that were obtained in the present study is the first step in the cross-cultural adaptation process. The translation procedures were based on the most widely used international guidelines. The results showed that the Brazilian DEBQ has satisfactory indices of verbal comprehension and high content-related validity. The psychometric properties of the instrument are ready to be tested so that it can be used in longitudinal and cross-sectional studies and by clinicians. 


\section{References}

Anastasi, A., \& Urbina, S. (2000). Testagem psicológica (M. A. V. Veronese, translator). Porto Alegre: Artes Médicas.

Baños Rivera, R. M., Cebolla Martí, A. J., Etchemendy, E., Felipe, S., Rasal Cantó, P., \& Botella Arbona, C. (2011). Validation of the dutch eating behavior questionnaire for children (DEBQ-C) for use with Spanish children. Nutrición Hospitalaria, 26(4), 890-898. doi: 10.3305/nh.2011.26.4.5238

Batista Filho, M., \& Rissin, A. (2003). A transição nutricional no Brasil: tendências regionais e temporais. Cadernos de saúde pública, 19(Supl 1), 181-191. doi: 10.1590/S0102-311X2003000700019

Beaton, D., Bombardier, C., Guillemin, F., \& Ferraz, M. B. (2002). Recommendations for the cross-cultural adaptation of health status measures. New York: American Academy of Orthopaedic Surgeons, 1-9. Retrieved from http://www.ortho.umn.edu/sites/ortho.umn.edu/ files/recommendations-cultural.pdf

Bozan, N., Bas, M., \& Asci, F. H. (2011). Psychometric properties of Turkish version of Dutch Eating Behaviour Questionnaire (DEBQ). A preliminary results. Appetite, 56(3), 564-566. doi: 10.1016/j.appet.2011.01.025

Cassep-Borges, V., Balbinotti, M. A. A., \& Teodoro, M. L. M. (2010). Tradução e validação de conteúdo: uma proposta para a adaptação de instrumentos. In L. Pasquali (Ed.), Instrumentação psicológica: Fundamentos e práticas (pp. 506-520). Porto Alegre: Artmed.

Conti, M. A., Slater, B., \& Latorre, M. R. D. O. (2009). Validity and reproducibility of Escala de Evaluación da Insatisfación Corporal para Adolescentes. Revista Saúde Pública, 43(3), 515-524. doi: 10.1590/S0034-89102009000300016

Danielsen, K. K., Svendsen, M., Mæhlum, S., \& Sundgot-Borgen, J. (2013). Changes in body composition, cardiovascular disease risk factors, and eating behavior after an intensive lifestyle intervention with high volume of physical activity in severely obese subjects: a prospective clinical controlled trial. Journal of obesity, 2013, 325-464. doi: 10.1155/2013/325464

Ferreira, L., Neves, A. N., Campana, M. B., \& Tavares, M. D. C. G. C. (2014). Guia da AAOS/IWH: sugestões para adaptação transcultural de escalas. Avaliação Psicológica, 13(3), 457-461. Retrieved from http://pepsic.bvsalud.org/scielo.php?script=sci_arttext\&pid $=$ S1677-04712014000300018

Fisberg, R. M., Marchioni, D. M. L., \& Colucci, A. C. A. (2009). Avaliação do consumo alimentar e da ingestão de nutrientes na prática clínica. Arquivos Brasileiros de Endocrinologia \& Metabologia, 53(5), 617-624. doi: 10.1590/S0004-27302009000500014

Flament, M. F., Hill, E. M., Buchholz, A., Henderson, K., Tasca, G. A., \& Goldfield, G. (2012). Internalization of the thin and muscular body ideal and disordered eating in adolescence: The mediation effects of body esteem. Body Image, 9(1), 68-75. doi: 10.1016/j. bodyim.2011.07.007

Goossens, L., Braet, C., Van Vlierberghe, L., \& Mels, S. (2009). Loss of control over eating in overweight youngsters: the role of anxiety, depression and emotional eating. European Eating Disorders Review, 17(1), 68-78. doi: 10.1002/erv.892

Hambleton, R. K. (2005). Issues, designs, and technical guidelines for adapting test into multiple languages and cultures. In: R. K. Hambleton, P. F. Merenda, \& C. D. Spielberger, (Eds.). Adapting educational and psychological tests for cross-cultural assessment (pp. 3-38). Mahwah: Lawrence Erlbaum.

Herman, C. P., \& Polivy, J. (1975). Anxiety, restraint, and eating behavior. Journal of abnormal psychology, 84(6), 666. doi: 10.1037/0021-843X.84.6.666"10.1037/0021-843X.84.6.666

Kaplan, H. I., \& Kaplan, H. S. (1957). The psychosomatic concept of obesity. Journal of Nervous and Mental Disease, 125, 181-201. Retrieved from http://psycnet.apa.org/record/1959-04434-001

Natacci, L. C., \& Ferreira Júnior, M. (2011). The three factor eating questionnaire-R21: tradução para o português e aplicação em mulheres brasileiras. Revista de Nutrição, 24(3), 383-394. doi: 10.1590/S1415-52732011000300002

Ouwens, M. A., van Strien, T., \& van der Staak, C. P. (2003). Tendency toward overeating and restraint as predictors of food consumption. Appetite, 40(3), 291-298. doi: 10.1016/S0195-6663(03)00006-0

Pasquali L. (2001). Princípios de elaboração de escalas psicológicas. In C. Gorenstein, L. H. S. G.Andrade, \& A. W. Zuardi (Eds.), Escalas de Avaliação Clínica em Psiquiatria e Psicofarmacologia (pp. 15-24). São Paulo: Lemos Editorial.

Porter, K. N., \& Johnson, M. A. (2011). Obesity is more strongly associated with inappropriate eating behaviors than with mental health in older adults receiving congregate meals. Journal of Nutrition in Gerontology and Geriatrics, 30(4), 403-415. doi: 10.1080/21551197.2011.623960

Ricca, V., Castellini, G., Sauro, C. L., Ravaldi, C., Lapi, F., Mannucci, E., ... Faravelli, C. (2009). Correlations between binge eating and emotional eating in a sample of overweight subjects. Appetite, 53(3), 418-421. doi: 10.1016/j.appet.2009.07.008

Schachter, S., Goldman, R., \& Gordon, A. (1968). Effects of fear, food deprivation, and obesity on eating.Journal of Personality and Social Psychology, 10(2), 91. doi: 10.1037/h0026284

Snoek, H. M., Van Strien, T., Janssens, J. M., \& Engels, R. C. (2007). Emotional, external, restrained eating and overweight in Dutch adolescents. Scandinavian Journal of Psychology, 48(1), 23-32. doi: 10.1111/j.1467-9450.2006.00568.x

Stunkard, A. J., \& Messick, S. (1985). The three-factor eating questionnaire to measure dietary restraint, disinhibition and hunger. Journal of Psychosomatic Research, 29(1), 71-83. doi: 10.1016/0022-3999(85)90010-8

Toral, N., \& Slater, B. (2007). Abordagem do modelo transteórico no comportamento alimentar. Ciência E Saúde Coletiva, 12(6), 1641-1650. doi: 10.1590/S1413-81232007000600025

Van Strien, T. (2010). Dutch Eating Behaviour Questionnaire: Manual. Amsterdam: Boom test uitgevers.

Van Strien, T., Frijters, J. E., Bergers, G. P. A., \& Defares, P. B. (1986) The Dutch Eating Behaviour Questionnaire (DEBQ) for assessment of restrained, emotional and external eating behaviour. International Journal of Eating Disorders, 5(2), 295-315. doi: 10.1002/1098-108X(198602)5:2<295:AID-EAT2260050209>3.0.CO;2-T

Van Strien, T., Herman, C. P., \& Verheijden, M. W. (2009). Eating style, overeating, and overweight in a representative Dutch sample. Does external eating play a role? Appetite, 52(2), 380-387. doi: 10.1016/j.appet.2008.11.010

Viana, V., \& Sinde, S. (2003). Estilo alimentar: adaptação e validação do questionário holandês do comportamento alimentar. Psicologia: Teoria, Investigação e Prática, 8(1-2), 59-71. 
Wardle, J. (1987). Eating style: A validation study of the Dutch Eating Behaviour Questionnaire in normal subjects and women with eating disorders. Journal of Psychosomatic Research, 31(2), 161-169. doi: 10.1016/0022-3999(87)90072-9

World Health Organization. (1998). Obesity: Preventing and managing the global epidemic. Geneva: World Health Organization.

\section{Sobre os autores}

Gabriela Salim Xavier Moreira é psicóloga (FFCLRP-USP), mestre e doutoranda em Psicologia pela Faculdade de Filosofia, Ciências e Letras de Ribeirão Preto-USP, pesquisadora do Laboratório de Nutrição e Comportamento e Laboratório de Pesquisa e Intervenção Cognitivo-Comportamental (LaPICC).

Diana Cândida Lacerda Mota é nutricionista, docente do Curso de Nutrição da Universidade de Ribeirão Preto - UNAERP/SP; mestre e doutoranda em Ciências pelo programa de Psicobiologia da Faculdade de Filosofia, Ciências e Letras de Ribeirão Preto/USP/SP; pesquisadora do Laboratório de Nutrição e Comportamento.

Luciana Lorenzato é nutricionista, com especialização em nutrição clínica e mestrado em Ciências (Psicobiologia) pela Faculdade de Filosofia, Ciências e Letras de Ribeirão Preto-USP, pesquisadora do Laboratório de Nutrição e Comportamento.

Idalina Shiraishi Kakeshita é nutricionista, com especialização em Educação em Saúde Pública e Psicossomática, mestrado e doutorado em Ciências (Psicobiologia), pós-doutorado em Psicologia, pesquisadora do Laboratório de Nutrição e Comportamento (FFCLRP).

Telma Maria Braga Costa é nutricionista, com especialização em Nutrição pelo Hospital das Clínicas da Faculdade de Medicina de Ribeirão Preto (FMRP - USP). Mestre e Doutora em Psicobiologia pela Faculdade de Filosofia Ciências e Letras de Ribeirão Preto (FFCLRP - USP). Pós-Doutora pela Cornell University, EUA. Professora e Coordenadora do Curso de Nutrição da Universidade de Ribeirão Preto (UNAERP). Professora Pesquisadora e Colaboradora do Laboratório de Nutrição e Comportamento do Departamento de Psicologia da Faculdade de Filosofia, Ciências e Letras de Ribeirão Preto (FFCLRP-USP).

Sebastião Sousa Almeida é psicólogo com mestrado e doutorado pela Faculdade de Medicina de Ribeirão Preto (FMRP-USP) com pós-doutorado pela Boston University-USA. Atualmente é Professor Titular do Departamento de Psicologia da Faculdade de Filosofia, Ciências e Letras de Ribeirão Preto (FFCLRP-USP) e pesquisador 1-B do CNPq. 
Página em branco deixada pelos autores 
Página em branco deixada pelos autores 
Página em branco deixada pelos autores 